
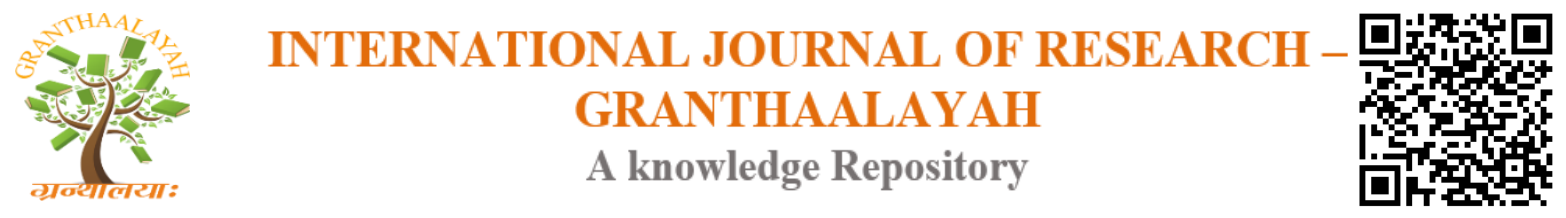

Science

\title{
DIGITAL ILLITERACY: A CONSTRAINT TO TECHNOLOGY EDUCATION ADVANCEMENT IN SOUTH-SOUTH REGION OF NIGERIA
}

\author{
Reagan N. Robinson ${ }^{1}$, Anthony N. Taneh ${ }^{2}$ \\ ${ }^{1}$ Department of Industrial Technology Education Ignatius Ajuru University of Education \\ Rumuolumeni, Rivers State \\ ${ }^{2}$ Department of Electrical/Electronic Engineering Kenule Saro-Wiwa Polytechnics Bori, Rivers \\ State
}

\begin{abstract}
Technology education is one the programmes designed to provide technical knowledge and skills necessary for economic development in Nigeria. But technology education programme has a constraint to its advancement which this study investigated. The study adopted the survey research method for the design. The population of the study was 453 persons comprised of 379 students and 74 technical teachers from one Technical College and a University with technology education department in each of the 6 states of the South-South geo-political zone. A simple random sampling technique was used to obtain a sample size of 188 which comprised of 33 technical teachers and 155 students. A 5-item questionnaire was used as the instrument for the study. The questionnaire item was followed by a single response category based on a 5-point rating scale format of Very High Extent (VHE), High Extent (HE), Moderate Extent (ME), Low Extent (LE) and Very Low Extent (VLE). A test re-test method was adapted to test the reliability of the instrument to obtain a coefficient of 0.73 . The data gathered was analyzed using mean and z-test analysis to answer the research question and hypothesis respectively. The finding revealed that digital illiteracy is a constraint to technology education advancement in Nigeria. Based on the findings, it was recommended that in order to enhance digital proficiency in technology education, government should adequately provide digital facilities in all technology education institutions in Nigeria.
\end{abstract}

Keywords: Digital; Illiteracy; Constraint; Technology; Education; Advancement.

Cite This Article: Reagan N. Robinson, and Anthony N. Taneh. (2018). "DIGITAL ILLITERACY: A CONSTRAINT TO TECHNOLOGY EDUCATION ADVANCEMENT IN SOUTH-SOUTH REGION OF NIGERIA." International Journal of Research - Granthaalayah, 6(11), 307-314. https://doi.org/10.29121/granthaalayah.v6.i11.2018.1132. 


\section{Introduction}

Broadly speaking technology is how people modify the natural world to solve problems. It is a body of knowledge and the systematic application of resources to produce outcomes in response to human needs and wants. However, Technology Education also known as Technical Education is a field of study that is designed to help students explore, discovers, experience, analyze and apply technology (Wakefield, 2015). It provides hands on problem solving experiences, concerned with developing insights into technology, evolution, utilization and significance; as well as its social, cultural and global impacts. Its curriculum is usually structured to develop technological literacy, which is the ability to adapt to change, solve problems, make decisions, think creatively, and apply concepts from science and mathematics and other related disciplines. Invariably Technology Education can also be referred to as the study of technology. It is designed to teach students to be prepared for a number of technology-related fields, and to learn about technology within specialized fields of study. Teachers cover topics related to technology processes, concepts and knowledge.

Technology Education has different specialization such as; Automobile technology, Building technology, Computer technology, Electrical technology, Electronic technology and Mechanical technology. Its broad philosophy is that students learn best through practically based skills; hence the curriculum adopts an activity-based and project-driven approach (Wakefield, 2015). As a field of study with specialty, it covers the human ability to shape and change the physical world to meet needs, by manipulating materials and tools with techniques. Technology education courses are commonly taught in both secondary and tertiary institutions. However, the first introduction of its concept typically takes place during primary school learning years, where students learn some fundamentals in projects development and discover topics related to product design, invention, problem solving and work safety. Technology education curriculum sometimes changes from country to country, state to state and from institution to institution. It is entirely different from general education and should not be confused with educational technology. Educational technology focuses on a narrower subset of technology which revolves round the use of technology in education as opposed to technology education's focus on technology's use in general (Dugger, William and Naik, 2001). However, Wakefield (2015) emphasized that technology education cannot be advanced in any nation with the presence of digital illiteracy. This view was supported by Asebiomo (2014) when he opined that digital illiteracy is a killer tool to the advancement of education in Nigeria of which Technology Education is one. This implies that with the presence of digital illiteracy, technology education cannot advance in Nigeria.

The term digital illiteracy emanated from the two words "Digital" and "Illiteracy". The word Digital refers to the electronic technology that expresses data or information (signals) in terms of two states known as digits. These states (digits) are ' 0 ' and ' 1 ' which can also be called binary digits. These digits of ' 0 ' and ' 1 ' can be used to represent incredible amount and types of data which can be transmitted from one person to another in the world (digital technology). Thus, data generated, transmitted or stored with digital technology is expressed as a string of 0's and 1's. Each of these state digits is referred to as a bit (and a string of bits that a computer can address individually as a group is called a byte). In a nut shell, any use of data or information in the form of digits for communication in the world is referred to as digital. Similarly, according to Merriam Webster's Dictionary, the word illiteracy refers to the inability to read and write. However, according to Asebiomo (2014), illiteracy can refer not only to the inability to read and write but 
also to a lack of knowledge and understanding in a particular subject area. Under this context, digital illiteracy can be defined as the lack of knowledge and understanding of using digital technology to locate, organize, evaluate, and create data (information) for communication. According to Asebiomo (2014), the use and manipulation of data in today's digital world cannot be separated from the internet and its efficiency is directly or indirectly tied to the internet. Hence it can be inferred that the eradication of digital illiteracy in the educational system of Nigeria, will give room to technological advancement in technology education. On a serious note students who are digitally illiterate may soon find themselves at just as much of a disadvantage as those who cannot read or write.

Digital illiteracy goes beyond the inability to use or operate the computer system to type and print documents. Somebody may know how to type and print documents with the computer system, yet be digitally illiterate. Digital illiteracy encompasses a wide range of inability to manipulate online data in order to achieve advancement in science, technological, commercial and governance (Herold, 2017). According to Adeoye and Adeoye (2017), this involves lack of skills in online data management. For instance, e-learning, video conferencing, online shopping etc. are all skills under the auspices of online data management which is digital literacy. Hence, the inability to possess these skills in this present digital world is a clear state of digital illiteracy (Herold, 2017).

In Nigeria technology education is generally designed to bring about industrial and commercial development which in turn is a key factor in economic development. This means that, the world of industries is the source of instructional content for technology education programme. According to Robinson (2006), it is the desire of every nation including Nigeria to be technologically developed and self-reliant. To be technologically developed and subsequently become self-reliant, a nation must utilize technology education as a fundamental. Imogie (2014) supported the view when he decried that no nation can develop to its fullest and keep pace with trends in science and technology without effective and efficient technology education programme. Technology education equips people with a broad range of knowledge, skills and attitudes that are now recognized as indispensable for meaningful participation in work and life (Okwelle and Ojotule, 2018). Generally, technology education has advanced to become the key element in all human endeavors all over the world especially in socio-cultural change (Wakefield, 2015), but Nigeria as a nation is yet to achieve the advancement of technology education that will enhance the socioeconomic life of its citizens. According to Okwelle and Ojotule (2018), the problem of technology education advancement in Nigeria is as a result of several constraints. Herold (2017) maintained, one of such major constraints is prevalence of digital illiteracy; which can be eradicated by the provision of online digital facilities in our institutions of learning. Similarly, UNESCO Institute for Statistics (2015) added; digital literacy is a requirement to the advancement of technology education, which is lacking in Nigeria. Lynch (2018) added, digital illiteracy will continue to be a constraint to the developmental stride of any learning institution if digital facilities are epileptic in services. Therefore the question; is digital illiteracy a constraint to technological education advancement in Nigeria? The answer to this question is the essence of this study.

\section{Statement of the Problem}

Technology education is one the programmes in Nigeria designed to provide technical knowledge and skills necessary for economic development of the nation. It is expected to apply scientific 
knowledge to solve problems for the convenience of the society, hence exposing students to the $21^{\text {st }}$ century professionalism of advancing technology. However, for these developmental strides to take place in Nigeria through technology education; there is need for the high level presence of digital literacy in the technology education institutions in Nigeria. This is to enable the technology education institutions to create the required proficiency that will bring Nigeria to the level of a developed nation. Unfortunately, it has been found out by several researchers that technology education institutions possess high presence of digital illiteracy. Students have been observed to be skilled with the use of social media instead of digital skills that will advance technology. UNESCO Institute for Statistics (UIS) has observed that Nigeria is one of the twentieth nations in the use of social media in the digital world, but still very far behind in possessing digital skills to advance technology. Hence, most Nigerian institutions are still referred to as digitally illiterate. UNESCO Institute for Statistics (UIS) further observed that this problem is as a result of some constraints like digital illiteracy in Nigerian institutions of learning. Therefore the question; is digital illiteracy a constraint to technology education advancement in Nigeria?

\section{Purpose of the Study}

The purpose of the study is to determine whether digital illiteracy is a constraint to technology education advancement in Nigeria? Specifically the study sought to;

1) Ascertain the extent to which digital facilities are made available in technology education institutions in the South-South region of Nigeria.

\section{Research Question}

The research question below was raised to guide the study;

1) What is the extent to which digital facilities are made available in technology education institutions in the South-South region of Nigeria?

\section{Hypothesis}

This hypothesis below was postulated and was tested at 0.05 level of confidence.

1) There is no significant difference between the mean responses of teachers and students on the extent to which digital facilities are made available in technology education institutions in the South-South region of Nigeria.

\section{Methodology}

The study was conducted using the descriptive survey design. The population of the study comprises of all the final year students and technical teachers of technology education institutions or departments in the South-South geo-political region of Nigeria. However, students and technical teachers of one technical college and a University with technology education department in each of the 6 states of the South-South region were used. This brings the population in consideration to 74 technical teachers and 379 students. The technical teachers in this context refer to teachers who handle practical oriented courses or subjects in the technology education institutions or departments in consideration. A simple random sampling technique was used to select a sample size of 33 technical teachers and 155 students, making a total sample size of 188. This comprises 
of Edo state with 3 teachers and 17 students; Delta state with 5 teachers and 20 students; Rivers state with 8 teachers and 43 students; Bayelsa state with 7 teachers and 34 students; Cross Rivers state with 4 teachers and 16 students while Akwa Ibom state had 6 teachers and 25 students. The sample size was obtained using the copies of the instrument retrieved from respondents.

A 5 item questionnaire each for technical teachers and students was used as instrument for the study. The instrument was developed by the researchers and was validated by 3 experts in technology education institutions and their views were added to improve the instrument. Each questionnaire item was followed by a 5 rating scale of Very High Extent (VHE - 5), High Extent (HE - 4), Moderate Extent (ME - 3), Low Extent (LE - 2) and Very Low Extent (VLE - 1). A test re-test method was adapted to test the reliability of the instrument to obtain a coefficient of 0.73 . The mean and z-test statistical analysis were used for the research question and hypothesis respectively. The null hypothesis is rejected if the $\mathrm{z}$-calculated exceeds the $\mathrm{z}$-table; otherwise, do not reject the null hypothesis.

\section{Presentation of Results}

The data gathered from the respondents were analyzed as follows;

Research Question 1: What is the extent to which digital facilities are made available in technology education institutions in the South-South region of Nigeria?

Table 1: Teachers and students responses on the extent of availability of digital facilities in technology institutions in Nigeria

\begin{tabular}{|c|c|c|c|c|c|c|c|}
\hline \multirow[t]{2}{*}{$\mathbf{S} / \mathbf{N}$} & \multirow[t]{2}{*}{ Items } & \multicolumn{3}{|c|}{$\begin{array}{l}\text { Technical Teachers } \\
\mathbf{N}=33\end{array}$} & \multicolumn{3}{|c|}{$\begin{array}{l}\text { Students } \\
\mathrm{N}=155\end{array}$} \\
\hline & & $\begin{array}{l}\text { Mean } \\
(\mathrm{X})\end{array}$ & $\begin{array}{l}\text { Std. } \\
\text { Dev. } \\
\text { (SD) }\end{array}$ & Dec. & $\begin{array}{l}\text { Mean } \\
(\mathrm{X})\end{array}$ & $\begin{array}{l}\text { Std. } \\
\text { Dev. } \\
\text { (SD) }\end{array}$ & Dec. \\
\hline 1 & $\begin{array}{l}\text { Computer workshop and laboratory are } \\
\text { available in your institution of } \\
\text { learning? }\end{array}$ & 2.0 & 1.2 & LE & 2.5 & 1.3 & $\mathrm{ME}$ \\
\hline 2 & 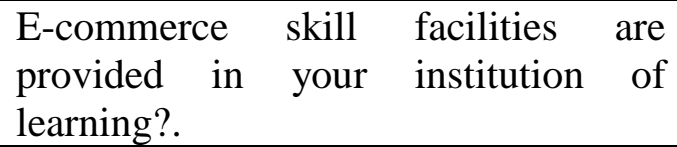 & 1.7 & 0.9 & LE & 1.9 & 1.2 & LE \\
\hline 3 & $\begin{array}{l}\text { E-learning facilities are accessible for } \\
\text { learning in your institution of learning? }\end{array}$ & 2.0 & 1.2 & $\mathrm{LE}$ & 2.1 & 1.3 & $\mathrm{LE}$ \\
\hline 4 & $\begin{array}{l}\text { Video conferencing facilities are } \\
\text { provided in your institution of } \\
\text { learning? }\end{array}$ & 1.9 & 1.1 & LE & 2.0 & 1.2 & $\mathrm{LE}$ \\
\hline 5 & $\begin{array}{l}\text { Internet Service Provider } \text { (ISP) } \\
\text { facilities are provided in your } \\
\text { institution of learning? }\end{array}$ & 1.7 & 0.8 & $\mathrm{LE}$ & 2.4 & 1.4 & $\mathrm{LE}$ \\
\hline \multicolumn{2}{|c|}{$\begin{array}{l}\text { Average Mean and Standard Deviation } \\
\text { respectively }\end{array}$} & $\sum X 1.86$ & 1.04 & $\mathbf{L E}$ & $\begin{array}{l}\sum X \\
2.18\end{array}$ & 1.28 & LE \\
\hline
\end{tabular}

Source: Researcher 
In table 1, all the items on technical teachers' response indicate a Low Extent (LE). This reveals that digital facilities are not available in the technology education institutions in Nigeria. Similarly, apart from item 1, all the items on the students' responses indicate a Low Extent (LE); revealing that digital facilities are not available in the technology education institutions in Nigeria.

The average mean response of students and technical teachers for the statement items were found to be respectively 2.18 and 1.86. These indicate Low Extent (LE), revealing that both teachers and students are of the opinion that digital facilities are not available in the technology education institutions in Nigeria.

Hypothesis 1: There is no significant difference between the mean responses of teachers and students on the extent to which digital facilities are made available in technology education institutions in the South-South region of Nigeria.

Table 2: Z-test analysis of the extent of availability of digital facilities in technology institutions in Nigeria

\begin{tabular}{|l|l|l|l|l|l|l|l|l|}
\hline & - & & & & & & & \\
SUBJECTS & $\mathbf{X}$ & SD & N & STANDARD ERROR & Z-CAL & Z-CRIT & d.f & P \\
\hline STUDENTS & 2.18 & 1.28 & 155 & 0.09 & 3.49 & 1.96 & 186 & 0.05 \\
\hline TEACHERS & 1.86 & 1.04 & 33 & & & & & \\
\hline
\end{tabular}

From table 2, since the calculated value of $z$ (3.49) is greater than the critical value of $z(1.96)$, the null Hypothesis is rejected. This means that there is significant difference between the mean responses of teachers and students on the extent to which digital facilities are made available in technology education institutions in the South-South region of Nigeria.

\section{Results and Discussions}

From Research Question 1, technical teachers and students responses revealed that the extent to which digital facilities are made available in technology education institutions in the South-South region of Nigeria is low. Meaning that, digital facilities are not adequately made available in the technology education institutions in Nigeria. This inadequate availability of digital facilities has brought about digital illiteracy which in turn is a constraint to technology education advancement in the South-South region of Nigeria. Lynch (2018) in support of the finding lamented that inadequate supply of digital facilities is the factor behind digital illiteracy in institutions of learning in developing nations of the world like Nigeria. According to Herold (2017), since the era of the digital revolution; digital illiteracy is a major clog behind the wheel of technology advancement in Nigeria, which is as a result of lack of digital facilities.

The finding also revealed that there is significant difference between the mean responses of teachers and students on the extent to which digital facilities are made available in technology education institutions in the South-South region of Nigeria. In other words, this means both the technical teachers and students in reality have divergent view on the extent to which digital facilities are made available in the technology education institutions in the South-South region of Nigeria. Nonetheless, they are both seen as two distinct groups playing different roles, but still 
agreed from the research question that the unavailability of digital facilities is a constraint to technology education advancement.

\section{Conclusions}

In this study, effort has been made to ascertain that digital illiteracy is a constraint to technology education advancement in Nigeria. The findings revealed that, there is inadequate availability of digital facilities in the technology education institutions in Nigeria. Hence, this inadequacy has caused digital illiteracy which has brought about a constraint to technology education advancement in the South-South region of Nigeria. Therefore, if all these required facilities are accorded their due priority by making them adequately available, digital illiteracy in technology education will be eradicated.

\section{Recommendations}

Based on the findings, the following recommendations were made.

1) Government should henceforth give priories to the introduction of E-learning in the teaching and learning process of technology education courses Nigeria.

2) In order to enhance digital proficiency in technology education, government should adequately provide digital facilities in all technology education institutions in Nigeria.

3) Government should adequately provide the technology education with funds to maintain digital facilities in the workshops and laboratories.

\section{References}

[1] Adeoye, A. A. \& Adeoye, B. J. (2017). Digital Literacy Skills of Undergraduate Students in Nigeria Universities. Library Philosophy and Practice (e-journal) https://digitalcommons.unl.edu/libphilprac/1665

[2] Asebiomo, A. M. (2014). Digital Literacy Initiative as a Transformational Tool for the Delivery of Teacher Education Programs for Professional Development in Nigeria. NERDC, Sheda Abuja. Information and Knowledge Management. 4(3): 18-23

[3] Dugger Jr., William E., Naik, Nitin (2001). Clarifying Misconceptions between Technology Education and Educational Technology. Technology Teacher. 61 (1): 31-35.

[4] Herold, B. (2017). Technology in Education: An Overview. Education Week, London. Retrieved 2018-07-03.

[5] Imogie, I. A. (2014). 100 years of western education in Nigeria: The wobbly tripod of growth, progress and shortcomings in university education in the journey so far. A keynote Address presented at 100 years of Nigeria Education: The Journey so far and prospect for the future, by Faculty of Education, University of Benin, Benin City, held from 21st-24th October.

[6] Lynch, M., (2018) The Edvocate: How can educators help their students navigate the digital world?Retrieved July 2018 at

www.theedadvocate.org External link and, www.thetechedvocate.org External link

[7] Okwelle, P. C. \& Ojotule, D. I. (2018). Constraints to students' effectiveness in practical skills acquisition in technical colleges in Kogi State, Nigeria. International Journal of Innovative Scientific \& Engineering Technologies Research. 6(1):1-9.

[8] Robinson, R. N. (2006). Technology in the Nigerian Economy. Journal of Vocational Education \& Technology (JOVET). 3(2): 25-31. 
[9] Robinson, R. N. \& Amadike, O. (2012). The Problem Affecting Computer Troubleshooting in Technical Institutions in Rivers State. Multidisciplinary Journal of Research Development (NARD). 18(1), 97-104.

[10] UNESCO Institute for Statistics (2015). List of countries by Literacy rate. From Wikipedia, the free encyclopedia. Retrieved July, 2018.

[11] Wakefield, J. (2015-02-02). How technology is changing schools. BBC News. Retrieved 2018-0703

*Corresponding author.

E-mail address: robinson_reagan@yahoo.com. 